\title{
O. Торбас
}

кандидат юридичних наук,

доцент кафедри кримінального процесу, детективної та оперативно-розшукової діяльності Національного університету «Одеська юридична академія»

\section{ЗАСТОСУВАННЯ РОЗСУДУ ПІД ЧАС ВИЗНАЧЕННЯ ПІДСТАВ ДЛЯ ПОЧАТКУ ДОСУДОВОГО РОЗСЛІДУВАННЯ}

У правовій доктрині достатньо велика кількість наукових робіт, присвячених абсолютно новій процедурі початку кримінального провадження по відношенню до старого кримінального процесуального законодавства. При цьому одні вчені вказують на правильність змін, які були запроваджені законодавцем [1; 2], інші, навпаки, стверджують, що процедура, встановлена в КПК України 1960 р., була більш удалою [3; 4]. Проте вчені, аналізуючи саму процедуру початку досудового розслідування, недостатньо уваги приділяють ролі власне суб'єктів та можливості застосування ними розсуду під час вирішення питання щодо початку досудового розслідування, хоча саме це питання потребує більш детального аналізу.

Згідно з ч. 1 ст. 214 КПК України, слідчий, прокурор невідкладно, але не пізніше 24 годин після подання заяви, повідомлення про вчинене кримінальне правопорушення або після самостійного виявлення ним із будьякого джерела обставин, що можуть свідчити про вчинення кримінального правопорушення, зобов'язані внести відповідні відомості до Єдиного реєстру досудових розслідувань, розпочати розслідування та через 24 години 3 моменту внесення таких відомо- стей надати заявнику витяг з Єдиного реєстру досудових розслідувань. У ч. 4 ст. 214 КПК України зазначено, що слідчий, прокурор, інша службова особа, уповноважена на прийняття та реєстрацію заяв і повідомлень про кримінальні правопорушення, зобов'язані прийняти та зареєструвати таку заяву чи повідомлення. Відмова у прийнятті та реєстрації заяви чи повідомлення про кримінальне правопорушення не допускається. Таким чином, законодавець досить чітко встановив обов'язковість початку досудового розслідування у разі звернення фізичної або юридичної особи 3 відповідною заявою до правоохоронних органів. Такий порядок суттєво відрізняється від того, який був установлений КПК України 1960 р., за якого в першу чергу необхідно було перевірити приводи та підстави для порушення кримінальної справи. Однак на даний момент кримінальне процесуальне законодавство такого порядку не встановлює, зазначаючи лише, що до внесення відомостей до ЄРДР допускається проведення лише такої слідчої (розшукової) діï, як огляд місця подіï. У такому разі можна зробити висновок, що в ЄРДР мають вноситися відомості щодо будь-яких заяв, які надійшли 
до правоохоронних органів. Проте такий висновок є лише частково правильним, адже ст. 214 КПК України надає уповноваженим посадовим особам більше свободи, ніж може здатися на перший погляд. У даному разі необхідно звернути увагу, що положення ст. 214 КПК України поширюються не на будь-які заяви та повідомлення, а лише на заяви та повідомлення про кримінальні правопорушення. Законодавець не уточнює, у чому полягає принципова відмінність, проте таке формулювання дало змогу здійснити нормативне уточнення на рівні підзаконних нормативно-правових актів.

Відповідно до п. 3 Розділу II Порядку ведення єдиного обліку в органах (підрозділах) поліції заяв і повідомлень про кримінальні правопорушення та інші події, заяви і повідомлення про інші події, що надійшли до чергової служби центрального органу управління поліцією, головних управлінь Національної поліції та їхніх територіальних (відокремлених) підрозділів (управлінь, відділів, відділень) поліції, у яких немає відомостей, що вказують на вчинення кримінального правопорушення, уповноважена службова особа після реєстрації в ITC IПНП (журналі ЄО) невідкладно, але не пізніше 24 годин передає керівнику відповідного органу (підрозділу) поліції або особі, яка виконує його обов'язки, для розгляду та прийняття рішення згідно із Законом України «Про звернення громадян» або Кодексом України про адміністративні правопорушення. Таким чином, можна зробити висновок, що в минулому окрема стадія порушення кримінальної справи, яка встановлювала порядок та строки перевірки заяв про злочини, була переформатована у звичайну перевірку заяв у момент ï надходження. Очевидно, що такий порядок має одразу низку недоліків. По-перше, перевіркою заяв та повідомлень займаються не слідчі, а лише «уповноважені службові особи», які повинні приймати заяви про право- порушення та реєструвати їх у журналі ЄО. По-друге, реально здійснити перевірку заяви щодо попереднього встановлення складну кримінального правопорушення черговому неможливо, адже такі особи не наділені жодними владними повноваженнями щодо проведення необхідних процесуальних дій. Окрім того, існує обмеження і в часі, адже з моменту реєстрації заяви до моменту внесення відомостей до ЄРДР має пройти не більше 24 годин.

Таким чином, можна констатувати, що законодавець замість того, щоб забезпечити реєстрацію всіх заяв та повідомлень із метою уникнення зловживання повноваженнями уповноваженими посадовими особами, дозволив перекласти обов'язок приймати рішення щодо початку досудового розслідування на осіб, які уповноваженні на прийняття заяв та повідомлень у правоохоронних органах. По факту стадія порушення кримінальної справи не була ліквідована, вона була лише спрощена у способах іiі реалізації. Відповідно, на початок досудового розслідування фактично впливає не слідчий чи прокурор, а черговий відповідного правоохоронного органу, який уповноважений на прийняття заяв. I саме він на власний розсуд, маючи змогу ознайомитися лише зі змістом заяви або повідомлення, повинен приймати рішення щодо направлення такої заяви для початку досудового розслідування або для надання відповіді згідно із ЗУ «Про звернення громадян» чи як адміністративне правопорушення.

Очевидно, що така ситуація не відповідає позиції законодавця, однак необхідно констатувати, що саме таким чином i має трактуватися положення ст. 214 КПК України. Це значно підвищує розсуд уповноваженого на прийняття заяв у правоохоронному органу, лишаючи слідчого без права впливу на такий процес. Відповідно, для усунення такої специфічної практики необхідно вносити 
зміни до чинного кримінального процесуального законодавства.

Така зміна, наприклад, може передбачити повернення стадії порушення кримінальної справи (провадження). Очевидно, що така позиція має багато сильних сторін, окрім того, вона дає змогу підвищити процесуальний статус слідчого шляхом надання йому права вирішувати, в яких випадках необхідно вносити відомості в ЄРДР, а коли - ні. Однак необхідно погодитися, що на даному етапі розвитку кримінального процесуального законодавства позиція щодо повернення стадії порушення кримінальної справи виглядає дещо радикально. Крім того, повернення такої процедури вимагатиме істотної зміни в КПК України, у тому числі й у самій структурі здійснення кримінальної процесуальної діяльності.

Більш доцільним виглядає вдосконалення понятійного апарату та уточнення процедури початку досудового розслідування. Передусім пропонується внести зміни до ст. 3 КПК України та доповнити іï таким визначенням: «7 $\left.{ }^{1}\right)$ заяви та повідомлення про вчинене кримінальне правопорушення - усне чи письмове звернення заявника або потерпілого до органу досудового розслідування чи прокуратури, зі змісту якого можна зробити попередній висновок про наявність події кримінального правопорушення». Запропоноване визначення потребує роз'яснення. Так, у даному разі було зроблено уточнення, що заяви та повідомлення можуть бути подані до органу досудового розслідування або до прокуратури. Цей перелік обгрунтовується тим, що тільки слідчі та прокурори уповноважені розпочинати досудове розслідування, а тому саме в органи досудового розслідування та прокуратури відповідні заяви та повідомлення можуть подаватися. Крім того, пропонується як окрему ознаку таких заяв та повідомлень визначити «можливість зробити попередній висновок про наявність події кримінального правопорушення». Очевидно, що таке формулювання $€$ оціночним, проте встановити будь-які чіткі критерії в даному разі неможливо. Як уже було зазначено, кримінальне процесуальне законодавство не надає жодних дієвих способів перевірити обгрунтованість заяви чи повідомлення про кримінальне правопорушення за 24 години з моменту іï подання (окрім огляду місця подіі), тому відповідні висновки мають робитися лише на підставі аналізу змісту заяви чи повідомлення. Очевидно, що такої інформації може бути замало, і в подальшому може бути встановлена відсутність події або складу кримінального правопорушення. Головне, щоб на момент реєстрації заяви уповноважена особа мала достатньо підстав для такого «Попереднього» висновку, який дає змогу прийняти рішення про початок досудового розслідування.

Очевидно, що лише таких змін буде недостатньо, адже саме процедура початку досудового розслідування залишається незмінною. У зв'язку із цим можна зробити висновок, що змін також потребує ст. 214 КПК України, тлумачення якої і викликає стільки труднощів. Розуміючи, що по факту сама процедура має лишатися незмінною, необхідно спробувати перенести акцент 3 особи, яка уповноважена на прийняття заяви, на слідчого та прокурора та встановити, що саме вони повинні здійснювати таку перевірку. Для цього пропонується ч. 1 ст. 214 КПК України викласти в такій редакції: «1. Слідчий, прокурор невідкладно, але не пізніше 24 годин після подання заяви, повідомлення про вчинене кримінальне правопорушення або після самостійного виявлення ним 3 будьякого джерела обставин, що можуть свідчити про вчинення кримінального правопорушення, зобов'язані перевірити заяву чи повідомлення на відповідність вимог, передбаченuх п. $7^{1}$ ч. $1 \mathrm{~cm} .3$ КПК України 
та внести відповідні відомості до Єдиного реєстру досудових розслідувань, розпочати розслідування та через 24 години з моменту внесення таких відомостей надати заявнику витяг 3 Єдиного реєстру досудових розслідувань. Слідчий, який здійснюватиме досудове розслідування, визначається керівником органу досудового розслідування».

Головною (та, по суті, єдиною) вимогою до заяв та повідомлень про кримінальні правопорушення $€$ можливість зробити такий попередній висновок про подію та склад кримінального правопорушення. При цьому свідомо не пропонується розширити повноваження слідчого або прокурора на початковому етапі кримінального провадження, адже це фактично повертає стадію порушення кримінальної справи та може стати причиною затягування 3 початком досудового розслідування внаслідок зловживань із боку відповідних працівників правоохоронних органів. Така перевірка заяв та повідомлень про кримінальні правопорушення має відбуватися лише шляхом ознайомлення зі змістом відповідного звернення та, за необхідності, проведення огляду місця події як невідкладної слідчої дії. Таким чином, пропонується закріпити в ст. 214 КПК України положення п. 3 Розділу II Порядку ведення єдиного обліку в органах (підрозділах) поліції заяв і повідомлень про кримінальні правопорушення та інші події, відповідно до якого таким видом діяльності займалася особа, уповноважена на прийняття заяв та повідомлень про кримінальні правопорушення. Такого роду зміна не дасть змоги в подальшому здійснювати занадто широке тлумачення ст. 214 КПК України та забезпечить максимально об'єктивну та фахову оцінку заяв та повідомлень про кримінальні правопорушення.

У cmammi автор аналізуе можливість застосування розсуду слідчим та прокурором під час визначення підстав для початку досудового розслідування. Автор зазначає, що хоча КПК України $i$ передбачає обов'язок вносити відомості до ЕРДР про початок досудового розслідування, практичне тлумачення ст. 214 КПК України дає змогу стверджувати про можливість застосування розсуду під час здійснення зазначеної проиедури. У підзаконних нормативноправових актах надається тлумачення, відповідно до якого особа, уповноважена на прийняття заяв та повідомлень, може самостійно вирішувати, чи міститься в таких заявах відомості про кримінальне правопорушення, таким чином, самостійно вирішуючи подальший рух кримінального провадження. Задля уникнення такого тлумачення ст. 214 КПК України автор пропонуе в кримінальному процесуальному законодавстві закріпити термін «заяви та повідомлення про кримінальні правопорушення», якими мають визнаватися усні чи письмові звернення заявника або потерпілого до органу досудового розслідування чи прокуратури, зі змісту якого можна зробити попередній висновок про наявність події кримінального правопорушення. Пропонується як окрему ознаку таких заяв та повідомлень визначити «можливість зробити попередній висновок про наявність події кримінального правопорушення». Очевидно, що таке формулювання е оціночним, проте встановити будь-які чіткі критерії в даному разі неможливо.

Також пропонується внести зміни до ч. $1 \mathrm{~cm} .214$ КПК Украӥни та викласти ї̈ в такій редакцї: «Слідчий, прокурор невідкладно, але не пізніше 24 годин після подання заяви, повідомлення про вчинене кримінальне правопорушення або після самостійного виявлення ним з будь-якого джерела обставин, 
що можуть свідчити про вчинення кримінального правопорушення, зобов'язані перевірити заяву чи повідомлення на відповідність вимог, передбачених $n .7^{1}$ ч. $1 \mathrm{~cm} .3$ КПК України та внести відповідні відомості до Єәиного реєстру досудових розслідувань...». Такого роду зміна не дасть змоги в подальшому здійснювати занадто широке тлумачення ст. 214 КПК України та забезпечить максимально об'єктивну та фахову оцінку заяв та повідомлень про кримінальні правопорушення.

Ключові слова: розсуд, початок досудового розслідування.

Torbas 0 . Usage of discretion in determining the grounds for beginning a pre-trial investigation In the article author analyses possibility of using discretion of investigator and prosecutor in determining the grounds for beginning of pre-trial investigation. Author notes that although the CPC of Ukraine set an obligation to enter information into the Integrated Register of Pre-Trial Investigations to begin a pre-trial investigation, practical interpretation of Art. 214 of the CPC of Ukraine allows the possibility of applying discretion in carrying out this procedure. By-laws provide an interpretation according to which a person authorized to accept applications and notifications may independently decide whether such applications contain information about a criminal offense, thus deciding on the further course of criminal proceedings. In order to avoid such an interpretation of Art. 214 of the CPC of Ukraine, author proposes to enshrine in criminal procedure legislation term «applications and notifications of criminal offenses», which should recognize as oral or written appeals of the applicant or victim to the pre-trial investigation or prosecutor's office, from which its possible to make conclusion about the existence of a criminal offense. It is proposed to define as a separate feature of such statements and notifications the possibility to make a preliminary conclusion about the existence of a criminal offense.

It is also proposed to change Part 1 of Art. 214 of the CPC of Ukraine and to state it in the following wording: "Investigator, prosecutor shall immediately, but not later than 24 hours after the submission of the application, notification of the committed criminal offense or after his independent discovery from any source of circumstances that may indicate the commission of a criminal offense, check the application or notification for compliance, provided for in paragraph $7^{1}$ of Part 1 of Art. 3 of the CPC of Ukraine and enter the relevant information in the Integrated Register of Pre-Trial Investigations ...". Such change will not allow in the future to carry out different interpretations of Art. 214 of the CPC of Ukraine and will provide the most objective and professional assessment of applications and notifications of criminal offenses.

Key words: discretion, beginning of pre-trial investigation.

\section{Література}

1. Столітній А.С. Підстави початку досудового розслідування. Науковий вісник Національної академії внутрішніх справ. 2014. № 4. С. 187-197.

2. Дрозд В. Окремі питання регламентації початку досудового розслідування в умовах проведення правової реформи. Підприємництво, господарство $і$ право. 2017. № 12. C. 268-272.

3. Середа Г.П. Прокурорський нагляд за додержанням законів при прийнятті, реєстраціі та вирішенні заяв $і$ повідомлень про злочини: деякі проблеми правового регулювання. URL: http: pravoznavec.com.ual period/article/ $285 / \% D 1$.

4. Аленін Ю.П. Початок досудового розслідування за КПК України 2012 року. Юридичний часопис Національної академії внутрішніх справ. 2013. № 1. С. 198-203. 